\title{
Duty of care and responsibilities of the management board of a German public company
}

by Frank Wooldridge

The above matters are regulated by the rather complex provisions of paragraph 93 of the German Aktiengesetz; the meaning of certain of them has given rise to some doctrinal controversies. The present article will be mainly concerned with paragraph $93 \mathrm{AktG}$, and will also deal with the prohibition of competition imposed on the members of the management board (board of directors) by paragraph $88 \mathrm{AktG}$.

\section{THE EFFECT OF PARAGRAPH 93(1) AKTG}

Paragraph 93(1) $A k t G$ provides that in carrying on business, the members of the management board shall exercise the degree of care of a diligent and conscientious manager. They shall not disclose confidential information or secrets of the company, especially trade and business secrets, which they have become aware of as the result of their service on the management board. Paragraph 93(1) has been said to impose an objective standard of conduct on the members of the management board: they are liable in damages to the company if they fail to attain the required standard. One of the leading textbooks indicates that this standard must be attained in the exercise of the specific tasks imposed on the management board by the relevant provisions of the Aktiengesetz, such as paragraphs 76, 80, 81, 83, 88, 90 and 92 thereof (see Uwe Hüffer, Aktiengesetz, 9th ed, pub C H Beck, 2010, p 493).

Confidential information consists of all information which has been acquired by the directors acting in this capacity, not necessarily as the result of their own efforts. Business secrets consist of all facts which are not published and which, according to the express or presumed intentions of the company, regard being paid to interests, should not be made public, provided that there is an objective need for such secrecy (BGHZ 64, 325). They indicate such matters as processes of manufacture or production, particularly of customers, and financial plans and decisions concerning staff. The duty to preserve confidentiality is not limited to the time when a director holds office, and is imposed on all the directors, including those who are appointed by the court, or who are deputies, or who represent the employees in accordance with the Codetermination Acts.
The requirement of confidentiality is inapplicable when the giving of information is in the interests of the company. Thus, such information may be given in the context of a due diligence exercise, or when shares are to be purchased on a stock exchange.

\section{Liability for breach of duties}

Paragraph 93(2) $A k t G$ provides that members of the management board who are in breach of their duties shall be jointly and severally liable to their company for any resulting damage. They shall bear the burden of proof in the event of a dispute as to whether or not they have employed the degree of care of a competent and conscientious manager. It is not entirely clear whether this provision is applicable both to their duties under the relevant provisions of company law and those governed by their contract of appointment, or whether it applies only to the first mentioned duties. (See Hüffer, op cit, p 500, who appears to take the latter view). The relevant paragraph applies to the deputies of members of the management board, and to members thereof who are appointed by the court; it is also applicable to those who are defectively appointed.

Members of the management board may not be found to have acted in breach of their duties to the company if they have merely been guilty of errors of judgment and mistakes. (An approach similar to that taken in the American "business judgment" rule has been taken by German courts in two important recent cases in which it was recognised that members of the management board must have a margin of discretion (Handlungspielraum), without which their tasks would be impossible. These two decisions are ARAG/Garmenbeck BGHZ 135, 244, 251 and Siemens/Nold BGH NJW 1996, 2815, 2816). However, the 
members of the management board are likely to incur liability to their company if they have acted in an absolutely unjustifiable manner. Such liability may be imposed on them if what they have done is clearly not in the interests of the company, or if they have taken unjustifiable risks when acting on its behalf. It will be necessary to show that there has been a defect in the management of the company, and that at the time of the relevant decision or transaction which gave rise to the liability, it was evident that there was such a defect, or that such evidence was available to the member of the management board against whom the action was brought on some other basis. In one case which was heard by the Oberlandsgericht of Dusseldorf, the impugned transaction involved the grant of a loan amounting to 55 million German marks by the financial board of a company to another company without taking security. The latter company became insolvent and the members of the financial board of the lender were unsurprisingly held liable (see Die AG (Die Aktiengesellschaft) 1997, 231, 234 and Hüffer, op cit at pp 493, 500-1, 504).

The fact that a member of the management board does not take part in a transaction does not exclude him or her from liability. Such a person cannot maintain that they have forgotten what has been told them about the transaction at a meeting of the board. A member of the management board must take account of the impressions that they have received of the activities of the other members of the management board at a meeting thereof. He or she has a right to object when there is concrete evidence that the responsible manager is not fulfilling their duties. This is apparent from a case (see BGHZ 133, 378 et seq) in which there was evidence that because the relevant company was in a situation of crisis employees' contributions to social security were not properly made. In other cases of a less blatant character, evidence will also have to be given of the failure of members of the management board to fulfill their duties.

A member of the management board is not liable to pay damages when they can show that they have exercised the necessary degree of care. Such a person does not incur liability when employees of the company have acted in a manner which has caused damage to it. It is necessary to show that the wrongful act or omission of the member(s) of the management board has caused the damage to the company in order for the latter to become liable. The damage is required to consist of a diminution in the company's assets in a manner which is inconsistent with its object. The making of social security contributions on behalf of the employees does not constitute such a diminution.

As already indicated, paragraph 93(2), sentence $2 \mathrm{Akt} G$ provides that the members of the board bear the burden of proving that they have employed the degree of care required of a diligent and conscientious manager. (They are required to bear the burden of proving that there was no wrongful act or omission on their part. The company must show the existence and amount of the damage, mention the act or omission of the relevant managers, and show the causal effect of the act or omission (see Hüffer, op cit, p 477). The action against the members of the management board is brought by the company's supervisory board, provided that the general meeting resolves by a simple majority in accordance with paragraph 147(1) $A k t G$. In addition, paragraph $148(2) A k t G$ provides that shareholders who hold at least 1 per cent of the share capital may require the court to bring a direct action in the company's name against the managers.

It does not always prove readily possible to show that the breach of duty by a manager has occurred which has resulted in damage. The courts have sometimes resorted to presumptions in order to overcome this difficulty. Thus where a significant amount of cash is missing, or goods are no longer in a warehouse, the courts have sometime presumed that this is the fault of the managers. However, the courts have not been willing to assume that any diminution in assets is necessarily the fault of the managers, and have sometimes applied a restrictive interpretation of paragraph 93(2) sentence $2 A k t G$ in such cases.

Managers who are jointly and severally liable to the company for damage caused to it in accordance with paragraph 93(2) $A k t G$ may claim a contribution from those of their number who can be shown to have a greater degree of responsibility for the relevant action. Shareholders who suffer injury as the result of acts or omissions of the management board cannot claim that paragraph 93(2) is a Schutsgesetz (protective statutory provision) intended for the protection of others, and requires reparation on the basis thereof. (Paragraph 823(2) of the Civil Code imposes an obligation to make reparation upon a person who infringes a statutory provision intended for the protection of others). Such protective provisions which may be invoked by shareholders suffering damage include paragraph 266 of the Penal Code and paragraph 399 AktG, which imposes criminal liability for making false statements.

It appears that third parties such as creditors cannot make claims against members of the management board of the company under paragraph 93(2) $A k t G$, or under that provision coupled with paragraph 823(2) of the Civil Code. It is apparent that creditors may do under paragraph 92(2) $A k t G$ which is concerned with the initiation of insolvency proceedings, and which has held to be a provision intended for the protection of others within the meaning of paragraph 823(2) of the Civil Code. In addition, members of the management board may incur delictual liability (tortious liability) towards third parties who are harmed by their acts or omissions. In a case decided by the German Supreme Court in 1994 (see BGHZ 125, 366) the managing director (Geschaftsfïhrer) of a German private company was held liable in tort for negligently failing to take precautions, where such 
negligence resulted in the infringement of another person's property rights. This decision has encountered substantial criticism in the relevant literature, because it has been contended that paragraph 823(2) of the Civil Code applies to positive action rather than to failures to act.

\section{The special rules contained in paragraph 93(3) Aktg}

The above provision stipulates that members of the management board shall in particular (sind namentlich) be liable for damages in nine specific circumstances. Eight of these circumstances involve the making of payments or distribution of shares or assets by the company, whilst the other consists of the issue of share certificates before the issue price has been fully paid. In each case the action must be one which is contrary to the Aktingesetz. (Note in this sense Hüffer, op cit, p 506 and Die Aktiengesellschaft, 2003, p 321. However, certain other provisions of the Aktiengesetz, ie paragraphs 92(2) and 400 thereof, which concerns representatives of the creditors of the company, may be regarded as protective statutory provisions for the benefit of creditors in the sense meant in paragraph 823(2) of the Civil Code).

\section{Exclusions of liability under paragraph 93(4) AktG}

According to the first sentence of the above provision, a member of the management board shall not be liable top the company for damages if they acted in accordance with a lawful resolution of the shareholders' meeting. Such a resolution must not be void or voidable. Every resolution of the general meeting concerning the management of the company passed without being requested by the management board is void, according to the provisions of paragraph 119(2) $A k t G$. The nullity of a resolution which is void may no longer be asserted if it has been registered in the Commercial Register and three years have elapsed. (See para 242(2) $A k t G$. In addition, by para 242(1) $A k t G$, the nullity of a resolution of a shareholders' meeting which contrary to para 130(1)(2) and (4) has not been recorded or properly recorded may no longer be asserted if the resolution has been entered in the Commercial Register.) A resolution which is voidable becomes no longer so within one month after its adoption, according to paragraph 246(1) $A k t G$. It appears that once the nullity of a resolution may no longer be asserted it can no longer be treated as a nullity under paragraph 93(4). The same would seem to be true of a voidable resolution once it may no longer be avoided.

It will be noted that the exclusion of a member of the management board from liability for damages is contingent on his or her acting on the basis of a lawful resolution of the general meeting. Such a person who acts on the basis of an unlawful resolution which he or she has himself or heself procured by giving wrongful information may still be liable (note in this sense Hüffer, op cit, p 507.)

According to paragraph 93(4) sentence $2 A k t G$, liability for damages shall not be excluded by reason of the fact that the supervisory board has consented to the act. The waiver or compromise of a claim for damages by the accompany against members of the management board is dealt with by paragraph 93(4) sentence $3 A k t G$. This text provides that such a transaction may take place upon the expiry of three years after the claim has arisen, provided that the shareholders' meeting consents thereto, and no minority share aggregate shareholding equals or exceeds one-tenth of the share capital records an objection in the minutes of the meeting. The meeting reaches its decision by a simple majority vote (para $133 \mathrm{AktG}$ ) and the relevant members of the management board against whom the claim is made have no vote.

The final sentence of paragraph 93(4) $A k t G$ provides that the foregoing period (of three years) does not apply if the person liable for damages is unable to make payments when they become due and enters into a composition with his creditors to avoid insolvency proceedings, or if the liability to pay damages is subject to an insolvency plan.

\section{Paragraph 93(5) AktG and the rights of creditors}

Paragraph 93(5) $A k t G$ sentence 1 provides that the claim of the company for damages may also be asserted by the company's creditors if they are unable to obtain satisfaction from the company. However, the sentence which follows it stipulates that in cases other than those set out in paragraph 93(3) of this rule shall apply only if the members of the management board have grossly violated the duty of care of a diligent and conscientious manager. It also makes it clear that in any litigation by the creditors, the burden of proving that they have acted as diligent and conscientious managers will be placed on the relevant members of the management board.

Creditors are treated as being unable to obtain satisfaction from the company if it cannot pay its debts: there is no need for them to attempt to levy execution against it. It follows from sentence 3 of paragraph 93(3) $A k t G$ that liability for damages to creditors may not be extinguished as the result of a waiver or compromise by the company, nor by the fact that the act which caused the damage was based on a resolution of the shareholders meeting.

The creditors must require payment to themselves, and not to the company. A member of the management board who has already been sued by the company for damages cannot raise the objection that such a claim is pending in litigation by the company's creditors against him or her. However, if a member of the management board satisfies the claim made against him by the company, his liability to the creditors is extinguished. It is possible for a creditor to bring an action against the company, and also to enforce it by execution proceedings directed against the company's claim for damages against a member of the management board, which have the effect of transferring this claim to the creditor. The use of such proceedings has practical advantages. 
The final sentence of paragraph 93(5) $A k t G$ deals with the effect of insolvency proceedings. It provides that if such proceedings have been instituted in respect of the company's assets, the administrator (Sachverwalter) or receiver (Insolvenzverwalter) shall exercise the rights of the creditors against the members of the management board during the course of the proceedings. The creditors themselves cannot bring an action against such persons during the course of the insolvency proceedings. The bringing of insolvency proceedings will interrupt any such action which is proceeding. The receiver may bring a claim against a member of the management board whose liability for damages to creditors is not extinguished by a waiver or compromise by the company. Furthermore, the receiver is not bound by the rule contained in paragraph 93(3) sentence $3 A k t G$, and may enter into compromises with creditors.

\section{Expiration of claims under paragraph 93(5) sentences 1-5 AktG}

The expiration of claims under the above provisions is dealt with by paragraph 93(5) sentence $6 A k t G$, which provides that such claims may no longer be made after the expiration of a period of five years. When claims are made under other legal provisions they are subject to the relevant limitation period for such provisions. The limitation period for an action against a member of the management board begins when the plaintiff company has become aware or failed to have become aware of the wrongful act of the relevant member of the management board or has failed to become so aware by reason of gross negligence on its part.

\section{COMMENTS ON THE ABOVE PROVISIONS}

The provisions of paragraph 93(5) $A k t G$ are somewhat detailed, and bear little resemblance to those contained in paragraphs 171-77 of the UK Companies Act 2006, which applies both to public and private companies. There is nothing in the Aktiengesetz or in the GmbH Gesetz which regulates private companies corresponding to the somewhat controversial provisions of section 172 of the Companies Act 2006, which imposes a duty to promote the success of the company on its directors, and there is an imposition of a duty of a pluralistic nature, requiring the directors to promote interests other than that of the company such as those of employees, customers or the environment, in paragraph $93 \mathrm{AktG}$. The existence of employee codetermination at the level of the supervisory board in large German companies having at least 2,000 employees may help to further the employees' interests.

\section{RULES GOVERNING THE PROHIBITION OF COMPETITION BY MEMBERS OF THE MANAGEMENT BOARD}

The above rules, which are an important feature of German company law, are contained in paragraph $88 \mathrm{Akt} G$. They reflect the fact that the members of the management board of a German public company have fiduciary duties to that company. (See the judgment of the Oberlandesgericht of Frankfurt to this effect, reported in Die Aktiengesellschaft, 2000, pp 518, 519). The ambit of the rules considered below is rather wide. In some other jurisdictions relevant similar rules may exist or be rendered permissible under the provisions of competition law.

\section{Rules contained in paragraph 88(1) AktG}

The above paragraph stipulates that, unless the supervisory board so consents, the members of the management board may neither engage in any trade nor enter into any transaction in the company's area of business on their own behalf, or on that of others. In the absence of such consent they may neither be a member of the management board nor a manager or general partner of another commercial undertaking (for example a public or private company, or a commercial partnership). The consent of the supervisory board may be granted only for a specific trade or business, a specific commercial enterprise, or for specific types of transactions.

Paragraph 88(1) $A k t G$ is designed to protect the company against certain activities by its directors, and to safeguard it from competition by them. It is appreciable to members of the management board and their deputies (but not to the members of the supervisory board) of the company whilst they remain in office. The prohibition in pursuing managerial activities in another commercial undertaking is not limited to undertakings in the same field of business, and does not apply to membership of the supervisory boards of such undertakings.

\section{The claim for damages under paragraph 88(2) AktG}

The above text provides that if a member of the management board fails to comply with the prohibition contained in paragraph 88(1) $A k t G$ the company may claim damages from them. It may instead require that such a member treats the transaction made on his behalf as having been made on behalf of the company, and give up any remuneration received from another person, or assign his rights to it, to the company. The latter alternative sometimes has the advantage that no depletion in the company's assets occurs, but its use requires that the company could have carried on the activity by itself, and is not prohibited from doing so. (Hüffer, op cit, p 456).

\section{The provisions of paragraph $88(3)$ AktG concerning limitation}

The above provision stipulates that the claims of the company shall be extinguished within three months after the other members of the management and the supervisory board come to know of the act giving rise to damages. Irrespective of such knowledge, such claims are barred upon the expiry of five years after the time when 
they have arisen. It appears that this rule does not apply where the supervisory board has not given its consent to the relevant act, or has given it improperly.

\section{Contractual provisions extending the ambit of the statutory rules}

It is possible to extend the statutory rules contained in paragraph $88 \mathrm{Akt} G$ to cover activities of a member of the management board which occur after their retirement. However, limits on competitive activities which occur after such retirement are regulated in paragraph 1 of the Law against Restraints upon Competition (Gesetz gegen Wettbewerbsbeschränkungen) and in paragraph 138 of the German Civil Code. Both these provisions require any prohibition of such activities to be required by the legitimate interests of the company and its undertaking, and to be limited in substance, time and extent according to the needs of the company for protection (see Hüffer, op cit, p 457 for further details.)

\section{CONCLUDING REMARKS}

The specific provisions contained in paragraph $88 \mathrm{Akt} G$ concerning competitive activities by the directors would not seem to be paralleled in many other jurisdictions. However, the pursuit of such activities will be subject to the relevant rules governing directors' fiduciary duties and of competition law in such jurisdictions. The provisions contained in paragraph $93 \mathrm{AktG}$, which have already been discussed above, appear to be of a more comprehensive and detailed nature than is the case in most other jurisdictions.

Dr Frank Wooldridge 